\title{
Socio-economic Development and International Migration: A Turkish Study
}

\author{
"The causes and consequences of continued internal as well as international \\ migration lie at the heart of the contemporary development problem" \\ M.P. Todaro ${ }^{1}$
}

Ahmet Icduygu, * Ibrahim Sirkeci, * and Gülnur Muradoglu*

\begin{abstract}
The root causes of international migration have been the subject of many studies, a vast majority of which are based on development theories dominated by economy-oriented perspectives. An underlying assumption is that poverty breeds migration. The results, and the conclusions drawn from these studies, differ widely. For instance, whether emigration increases when poverty becomes more extreme, or less extreme, or why it reaches certain levels, are issues on which research still offers a mixed answer.

This article investigates the relationship between economic development and migration by taking into consideration the degrees of economic development that form thresholds for migration. It focuses on recent evidence on the development-emigration relationship in Turkey which reflects a dimension of the dynamics and mechanisms facilitating or restricting migratory flows from the country.

Using data from the 1995 District-level Socio-economic Development Index of Turkey (DSDI) and the 1990 Census, the principal aim of the article is to provide an analytical base which identifies degrees of local level of development in Turkey, relate these to international migration flows, and examine patterns of the development-migration relationship.
\end{abstract}

* Department of Political Science, Bilkent University, Ankara, Turkey. 


\section{INTRODUCTION}

This article contributes to the debate on how socio-economic development facilitates or impedes emigration. The view that "poverty breeds migration" has been repeated frequently; the generalization of "underdevelopment and migration" is fairly well established; and "push and pull factors" are repeatedly compiled to examine the development-migration relationship. ${ }^{2}$ However, both the results and the conclusions drawn from the relevant literature vary. For instance, the relationship between emigration and changing levels of poverty is an issue on which research still offers a mixed answer (Hammar, 1995: 175-176; Icduygu, 1995: 4-5; Hammar et al., 1997: 1-19; Faist, 2000: 1-8). Continuing debates about the relationship between emigration and development also reflect a growing awareness that the picture is much more complex than often suggested. Central to this debate has been the re-emergence of studies on the root causes of international migration; ${ }^{3}$ a re-assessment of the dynamics of emigration in developing countries; ${ }^{4}$ and a re-examination of the role of migration networks in migration processes. ${ }^{5}$ While the appeal of the question, "why migration, or why not migration in certain economic and social conditions" is not new, more knowledge is needed on how levels of socio-development are associated with emigration. ${ }^{6}$

The aim of the present article is to investigate the relationship between socioeconomic development and emigration by taking into consideration the degrees of socio-economic development that form thresholds for emigration. We take the case of Turkey, a particularly appropriate country for such a study, first because of its high rate of long established emigration and, second, because its experience of emigration is diverse enough to reflect the impact of various levels of development on emigration. The impact of socio-economic development on emigration from Turkey also appears to have articulated into changing forms of emigration in ongoing processes - from labour migration to family reunion, marriage migration and asylum seeking.

The article addresses three propositions: (1) that emigration flows tend to increase and then decrease at a certain level of socio-economic development, indicating that neither very rich nor very poor areas of a country are primarily involved in the emigration process but rather the areas in-between; (2) that deviations from the patterns of these economy-oriented emigration flows can be the outcome of other social and political processes of migratory regimes; and (3) that adequate information currently does not exist to pinpoint these processes and to articulate them in the form of testable hypotheses.

These propositions require further clarification. Emigration flows differ considerably in formal as well as informal classification of their causes and in the structural status of their perpetuation. For the most part, causes are defined in "natural economic terms", or in terms of rationally defined economic attributes. 
There is no doubt that the notion "pure economic emigration flow" is a theoretical abstraction rather than a description of reality. Demographic characteristics, socio-economic conditions, and political and historical processes along with individual factors - shape the genesis of emigration as well as its trends and patterns. When the economy-oriented perspective on emigration fails to account for various internal and external factors that affect both initiation and perpetuation of the movement, it becomes clear that there is a need to elaborate other social and political processes involved. This article therefore explores the role of socio-economic differentials in emigration tendencies in the various districts of Turkey and aims at providing an analytical base designed to identify the degrees of local level of development in Turkey, relate these to emigration flows, and thus explain the development-emigration relationship. However, this type of analysis can identify only the general pattern of the development-emigration relationship; it cannot determine the details of its dynamics and mechanisms.

\section{THEORETICAL CONSIDERATIONS: DEVELOPMENT AND EMIGRATION}

It has been widely argued that there is not yet a coherent, comprehensive theory of international migration. As proposed by Massey et al. (1993: 432), there are fragmented sets of views isolated from each other. What is needed is a theory that incorporates the variety of perspectives, assumptions and models provided by different disciplines. While this article does not provide a direct contribution to the construction of such a comprehensive theory, it adds some aspects of the development-emigration question to theoretical perspectives and research findings.

The development-emigration relationship is usually examined within two different contexts: one takes development, or underdevelopment, as a cause of emigration; the other considers it as a consequence of emigration. ${ }^{8}$ The focus of the present article is on the former postulate. In general, views on the initiation of migration revolve around the economic causes of migration. Massey et al. (1993) place these in four categories: the "neoclassical economics model" which focuses on differentials in wages and employment conditions between countries and on migration costs, taking migratory movement into account as an individual decision for income maximization; the "new economics of migration" model which considers conditions in a variety of markets (not just labour markets) and views migration as a household decision; the "dual labour market theory" and the "world systems theory", ${ }^{10}$ both of which ignore micro-level decision processes (individual or household) and focus on forces operating at higher levels of labour markets within the international context.

These models consider international migration as comprising persons who wish to make more money than they earn in their own country because of wage 
differentials between different labour markets. However, international migratory regimes also provide evidence of thresholds of socio-economic development which play a role in pushing people from one country to another. It is also evident that some migratory pressures based on socio-economic causes do not automatically result in massive emigration. Other social, political, cultural, and demographic factors intervene as determining powers. Piore (1980: 135-140), for instance, draws attention to emigration of upwardly mobile middle-class persons from the middle-level developed areas. ${ }^{11} \mathrm{He}$ states that the background of persons from these areas "provides them with the perspective on the society and the knowledge of its operation required to put together the necessary institutions that will bridge the difference between the countryside in an underdeveloped area and the emigration procedure of a developed industrial nation" (1979: 138). Portes and Bach (1985: 4-5), analyse labour migration from Central and Latin America to the US and point out that most of the immigrants came from somewhat developed regions, for instance, the urban working class of Mexico rather than the most impoverished peasant-dominated states; from Argentina, the most developed country in Latin America instead of Bolivia or Peru, the less developed.

Hammar's (1995: 175) question, Why have many more emigrants not left the South?, finds answers at this point. ${ }^{12}$ This question represents at once an expansion of theoretical scope and a challenge to former explanations of international migration. Preceding studies predicted that large flows of migration from South to North would occur as a result of underdevelopment of the South. These views were based on such factors as high unemployment rates, extreme gaps in income and living standards compared with the North, unstable political orders, and poor governance which often prevail in the South (Hammar, 1995: 175). Referring to the US Commission for the Study of International Migration and Cooperative Economic Development report, which concluded that economic development does not reduce migration from Mexico to the US, Hammar (1995: 176) answered his own question: "Emigration may be expected to grow when poverty becomes less extreme, when literacy, basic education, and professional skills are more widespread, and when young women and men are ready to think not only about the next few days or weeks but about their own future and their children's."

This means that out-migration increases once a threshold of socio-economic development is established. Another dimension, significant for emigration to developed regions, is created by labour recruitment and dual market approaches. These emphasize the demand (for labour) from developed regions and capital (investment) in underdeveloped regions of the world. This process can be formulated in two steps. First, capital investment in an underdeveloped region builds the mechanisms (for instance, passports and increased airline flights to developed countries) for prospective migration. ${ }^{13}$ Second, a relatively small amount of skilled labour moves into the underdeveloped region and a large 
amount of relatively skilled (with respect to other natives of the region) labour flows to the developed countries. In short, the demand in developed regions is for persons from relatively developed regions of underdeveloped countries. The end product of this process is that "international labour migration is largely demand-based and initiated by recruitment on the part of employees in developed societies, or by governments acting on their behalf”' (Massey et al., 1993: 444).

The main arguments of Piore (1980), Portes and Bach (1985), Massey et al. (1993), and Hammar (1995) provide a theoretical base for the propositions through which we investigate the complex nature of socio-economic development and emigration. Although Massey et al. (1993) do not focus particularly on the core of our research question, their efforts, findings and integration of contemporary theories of international migration enable us to delineate the origins of emigration and its perpetuation. Portes and Bach (1985) draw the general picture of mobility regimes in which emigration occurs from regions with mid-level socio-economic development towards relatively developed regions. Along the same line, Piore (1980) implies that although middle-class migration eventually generates a migration stage in which lower and upper sectors of the population also become mobilized towards the developed countries, the central position of middle-class migration often remains dominant. It is within this context that Hammar's (1995) study, asking why there is not more emigration from some impoverished regions, questions deviations from the patterns of economy-oriented emigration and stresses other social and political factors affecting emigration.

We need to know more about the relationship between a certain level of socioeconomic development in a given region and a decreasing and increasing migration trend in that region; and about other social, political, cultural, and demographic causes of emigration at the individual and community level. There is a need for studies on the complex relationship between emigration and economic development, poverty, social development, mobility, culture, population increase, political stability, and violations of human rights and freedoms. An analysis of this kind points to the significance of a great number of social, political, cultural and demographic factors on which the migratory flows depend, besides a number of economic factors. Our attention in this article is directed to the measurement of how socio-economic factors make, or do not make, migration possible for people living in the various districts of Turkey.

\section{STUDY SETTING: EMIGRATION FROM TURKEY}

Turks were latecomers to the international migration market after World War II. Four successive periods are identified after 1961 mainly as a result of changes within receiving countries. The first (1961 to 1974) was characterized by massive labour migration to Western Europe; the second (1974 to 1980) began 
with the oil crisis, causing a decline of Turkish labour migration to Western Europe and precipitating the beginning of emigration to Arab countries; the third (in the 1980s) was dominated by labour flows toward Arab countries. Since the early 1990s emigration has been characterized by a turn of labour flows from Arab countries to countries which have been reconstructed after the collapse of the USSR.

Although Turkey began exporting labour only after the negotiation of an official agreement with the Federal Republic of Germany in 1961, by 1970 it had become one of the largest suppliers of new workers to various labour importing countries (Paine, 1974: 59; Icduygu, 1991: 39). Preceding the agreement with Germany, the Western European labour market had already drawn a number of workers from Turkey; however, the size of this frontier movement was small, sporadic and relatively unknown because workers often migrated illegally, owing to difficulties in obtaining passports and visas (Abadan-Unat, 1976: 14; Lieberman and Gitmez, 1979: 204). Within the context of European migratory regimes in the 1960s, structurally organized emigration from Turkey was not possible without the negotiation of an official agreement between governments. After the new constitution of 1961, Turkey's first Five-year Development Plan (1962-1967) evaluated the "export of surplus labour power" as an aspect of development policy in terms of remittances and reduction in unemployment. To promote this policy, Turkey first signed a bilateral labour recruitment agreement with Federal Germany in 1961, followed by similar bilateral agreements, specifying general conditions of recruitment, employment and wages, with Austria, the Netherlands, and Belgium (1964), France (1965) and Sweden and Australia (1967). Less comprehensive agreements were signed with the United Kingdom (1961); with Switzerland (1971); with Denmark (1973); and with Norway (1981) (Franz, 1994: 307). These agreements shaped the initial stages of migratory flows even if they did not make any considerable impact on later stages of the flows. In other words, migratory movements have gained their own dynamics and mechanisms quite independent of the previously structured measures of bilateral migration agreements.

In the broadest terms, the flow of Turkish workers to Western European countries began in the early 1960s, gathered momentum in the mid-1960s, expanded dramatically in the late 1960s and early 1970s, and ceased in the 1970s (Figure 1, page 55). The number of workers going abroad increased immediately after 1961 and peaked at 66,000 in 1964. The recession of 1966-67 caused a rapid decline in numbers which then increased sharply after the recession. In 1974 there were only 17,000 departees. Economic stagnation had led Western European governments to curtail the entry of workers. The year 1975 marked the end of large-scale Turkish labour migration to Europe (Table 1, page 57).

In the following years the direction of Turkish emigration shifted to the oil exporting countries of the Middle East and North Africa (Figure 1). One should 
note, however, that although the labour movement from Turkey to Western Europe ceased in the early 1970s, migration to that region did not end; it took other forms such as family reunion, refugee movement and clandestine labour migration (Bocker, 1995: 167; Icduygu, 1996: 5). Even today, through these various types of migration, over 300,000 persons move annually from Turkey to Europe.

In the late 1960s, under pressure of unemployment, the Turkish government moved quickly to search for a new market to allow the labour exporting process to continue at a time when the doors of Europe were closed to immigrant workers. Turkish emigration to Australia, as well as to Arab countries, began under these circumstances. The timing of the bilateral labour agreement with Australia in 1967 reflected government emigration strategy of "falling back on another country if one showed signs of saturation and diminished absorption ability" (Bahadir, 1979: 105). Between 1968 and 1995, more than 12,000 workers went to Australia and numbers have fluctuated between 200 and 500 persons each year since 1975. It should be noted, however, that the number of emigrants to Australia represented only a very small fraction of emigration from Turkey (Young, 1983: 35).

During the third period, male labour emigration from Turkey to Arab countries, mainly Saudi Arabia, Libya and Iraq, remained high. Turkey's search for new receiving countries corresponded with the need for labour in these countries. As stated by Appleyard (1995: 3), after 1973, when oil prices rose dramatically, thus increasing the income of the oil-exporting Arab states with very small populations, demand for labour led to large flows of contract workers from other developing countries. Migration from Turkey occurred within this broader context. However, by the mid-1990s, due partly to the completion of large scale infrastructural projects in oil-exporting countries, and partly due to unfavourable circumstances caused by the Gulf crisis, the number of Turkish workers in Arab countries declined. Indeed, it fell from 250,000 in the late 1980 s to 140,000 to the early 1990 s.

The final phase of Turkish labour emigration began with flows of relatively small groups of workers to countries of the former USSR. As emphasized by Gokdere (1994: 39), some of the newly emerging states in the region launched reconstruction programmes, and the active involvement of various Turkish firms in these programmes led to a significant level of project-tied and job-specific migration. In terms of its impact on the continuity of emigration from Turkey, migration to countries of the former USSR was very important. In a period of reduced flows to labour-receiving Arab countries after the Gulf crisis, migration to countries of the former USSR became a "remedy" for emigration pressure in Turkey. Labour migration from Turkey to these States increased from 8,000 in 1992 to over 20,000 in 1993 and over 40,000 in 1994. 


\section{DATA AND METHOD}

In terms of the two dimensions of the research question under consideration, this article combines information from two sources: the 1995 District-level Socioeconomic Development Index (DSDI) ${ }^{14}$ in Turkey; and the 1990 Turkish Census. The DSDI, readily available from the State Planning Organization (SPO) of Turkey, contains a comprehensive list of 32 components of district-level socioeconomic development in the country, including such indicators as population, employment, education, health, manufacturing industry, construction, agriculture, communication, and financial indicators. As indicated in Table 2 (page 58), DSDI takes index values in the range of -1.35 to 7.74 , the former indicating the lowest and the latter the highest level of development at the district level. The distribution of the DSDI values are leptokurtic and highly skewed, as indicated by the skewness coefficient and the distance between the mean $(0.001)$ and the median $(-0.25)$.

Based on a relative standard, DSDI represents an assessment of the extent to which each district of the country has a certain level of socio-economic development. The basic advantage of using DSDI is its multi-dimensional character, containing both social and economic indicators rather than a unidimensional "economy-dominant" criterion.

Administratively, Turkey is divided into 79 provinces. These are further subdivided into 858 districts, geographical areas with separate administrations subject to provincial governors, and then to central government. From an analytical standpoint, this study required a mix of data on socio-economic development and emigration within the 858 districts. Use of data from the 1990 Census centres around the question (in that Census) related directly to the participation of persons in emigration: Household question $5^{15}$ - How many household members are absent now; are they in the country or abroad? Information of this kind enables calculation of the proportion of persons who are emigrants from each of the 858 districts. As presented by the wide range of emigration (the minimum being 0.2 per cent and the maximum 31.1 per cent (Table 1)), the percentage of households that have emigrants varies considerably across districts. Also, the distribution of emigration data is leptokurtic and skewed; while mean emigration is 3.51 per cent, the median is only 2.1 per cent.

In order to construct an abstract model to indicate the nature of the relationship between socio-economic development and emigration, it is necessary to find a way to use data classified in some groupings as reflected by the mean scores of both socio-economic development and emigration. We therefore considered the possible differences in mean emigration levels as due to changes in the development levels of the districts represented by the three groupings used in this study: (a) 6-level classification of the DSDI scores by the SPO, (b) deciles of the DSDI scores, and (c) 7-level geographical classification of the DSDI scores. 
The 858 districts were allocated into six groups according to the SPO's classification of different levels of the socio-economic development based on both in-group homogeneity and out-group heterogeneity of the DSDI scores prepared by the SPO. While the first group (Development Level 1) indicates the highest development level, which corresponds to the DSDI values ranging between 7.77 and 3.15, the sixth group (Development Level 6) refers to the lowest development level with the DSDI values in the range -0.84 and -1.34 . The ranges for the other groups are: the second group 2.98 to 0.89 ; third group 0.86 to -0.06 ; fourth group -0.07 to -0.64 ; and fifth group -0.65 to -0.83 . Although the resulting six groups are homogenous in terms of development levels, the number of districts in each group is highly variable due to the skewness of the distribution. The most developed group (Development Level 1) accommodates only 15 districts, the second contains 103 , the third 209, the fourth 326, the fifth 195 and the least developed (Development Level 6) 200 districts.

In view of the variation in number of districts in each development level according to the SPO's classification, we utilized a decile grouping by dividing our DSDI distribution into ten equal parts. Correspondingly, the 858 districts are ranked according to their DSDI scores in ascending order. In Development Decile 1, representing the highest development level, each development decile contains 86 districts except for the first two, which contain 85 districts. The mean DSDI score for the first decile (Development Decile 1) is 2.35 and for the last decile (Development Decile 10) -1.06, with DSDI values falling within this range for the other eight deciles.

Finally, a conventional regional breakdown of the country was used to elaborate the relationship between development and emigration. Seven geographical regions - Marmara, Western, Southern, Northern, Central, South-eastern and Eastern - also reflect to some extent differences in levels of socio-economic development. The Marmara region, the most advanced in the country, has a mean DSDI score of 0.66; the Eastern region, the poorest, has a mean DSDI score of -0.62 . In terms of their ranks from the most developed region to the least developed, the order of the remaining regions is Western, Southern, Northern, Central, and South-eastern.

\section{FINDINGS}

This study elaborates and applies a socio-economic-development-based approach to the measurement of the differentiated levels of emigration from the different areas of Turkey. Figure 2 (page 56) shows the mean DSDI scores according to the SPO classification, together with the mean proportions of emigrant households from each of these groups. In each twin-bar, the first bar represents the mean scores of DSDI classification of the SPO from 1 through 6 , and the second bar denotes the mean migration at that development level. According to Figure 2, 
the mean emigration level increases with the declining level of socio-economic development, reaching its highest level at the fifth DSDI group, if the most developed region (the first region with the DSDI scores between 7.77 and 3.15) is excluded. However Table 2 shows that the difference in the mean emigration levels of the most developed two regions is not significant and we can safely argue that the mean emigration level increases as the level of socio-economic development declines and reaches its zenith point at the fifth DSDI group. The second bar of the fifth twin-bar shows that while mean migration scores 4.8 per cent, the mean development index is -0.7 . A declining level of migration becomes clear at the lowest level of socio-economic development, as it is seen in the sixth twin-bar where the mean migration is around 3.2 per cent and the mean development index is -1.0.

Table 2 presents the tests for differences in mean emigration at different development levels according to the SPO classification. T-tests have been conducted for the differences in mean emigration proportion at each development level and the results indicate that mean emigration proportions at Development Levels 4 and 5 ( 4.0 and 4.8 per cent respectively) are statistically significantly different from the mean emigration proportions at other Development Levels. Also, the mean emigration proportion of Development Level 5 (4.8 per cent) is significantly higher than the mean emigration proportion of Development Level 4 (4.0 per cent), as a consequence of which we conclude that the highest proportion of emigration is observed at Development Level 5. Significant differences in the mean proportions of emigration are not noticed for the most developed three groups of districts (Development Levels 1, 2 and 3) and the least developed (Development Level 6).

The most obvious conclusion to be drawn from Figure 2 and Table 2 is that the level of emigration from a region is highly sensitive to the socio-economic development level there, and that the highest level of emigration often occurs in the relatively less impoverished areas of the most underdeveloped regions.

The fact that the most developed districts (with mean development scores of 4.2) also have a quite high figure of mean emigration ( 2.7 per cent) is undoubtedly attributable to the unique emigration status of various developed districts of the country: the most developed districts, providing potential emigrants with various formal and informal opportunities to facilitate emigration, have probably been transit migration areas for thousands of emigrant families prior to departure.

Based on the nature of the 1990 Census data used in this study many "most developed" districts have been classified as those heavily involved in emigration. Actually, many emigrant households enumerated in the developed 
regions were households that had already migrated from less developed districts of the country to these developed districts.

A similar relationship between emigration and socio-economic development is also evident when the DSDI figures are elaborated within the context of deciles as shown in Figure 3 (page 56) and Table 3 (page 59). Considering the significant variation among the three deciles presented in Table 3 , we can safely argue that the emigration level rises from approximately 2.3 per cent to a maximum 5.4 per cent at the eighth decile and then declines to 2.9 per cent at the tenth decile, the least developed group. These comparisons again imply two conclusions that are very similar to the above cases: first, a skewed distribution of mean emigration based on socio-economic development characterizing the highest level of emigration in the relatively less impoverished areas of the most underdeveloped regions; and second, the particular emigration position of the most advanced districts deviating from others.

The mean emigration proportions and the mean DSDI scores presented in Figure 4 (page 57) and Table 4 (page 59) are based on the conventional geographical regions of the country. They also indicate a bell-shaped relationship between emigration and socio-economic development; emigration increases as regions get poorer, but when the level of socio-economic development reaches a certain low level, emigration proportions also begin to decline. The emigration pattern that emerges within the context of geographical regions is also similar to those observed in previous classifications of the DSDI scores. Mean emigration gradually increases from the statistically significant minimum score of 1.8 per cent in the Marmara region (the most advanced area of Turkey), to 2.5 per cent in the Western region, and to 3.6 per cent in the Southern region. After reaching its peak in the Northern region with the figure of 5.0 per cent, it begins to decline to 3.9 per cent in the Central region and 2.4 per cent in the South-eastern region. Corresponding mean DSDI scores are $0.66,0.46,0.30,-0.04,-0.12,-0.61$ respectively for those regions. However trends show that the poorest region, Eastern Turkey, with the mean DSDI score of -0.2 , has a significantly higher level of emigration (4.25 per cent) than neighbouring less impoverished districts of the South-eastern region with an emigration level of 2.4 per cent, which is very similar to the Western region (Table 4).

The deviant emigration status of the Eastern region, where despite its own lowest mean DSDI score there is presence of a relatively high level of emigration, can be explained by several factors: long-established emigration history of certain districts in the region (for instance, those from Erzurum, Erzincan, Tunceli, and Malatya); presence of some exceptionally developed provinces which generate emigrants of their own, or transfers those from the neighbouring areas (for instance, Erzurum, Erzincan, Malatya, and Van); the particular status of the region for politically motivated emigration, ${ }^{16}$ again either generating its own 
mainly Kurdish emigrants, or playing a role of transit zone for Kurdish emigrants of the South-eastern region.

\section{CONCLUSION}

Most previous research into the question why people migrate has been directed to economic conditions, as could be anticipated from both the unquestioned importance of these conditions for migration and the relative ease with which they can be measured. However, both the results of previous research and the conclusions drawn from them, are often not satisfactory. The degrees to which economic development forms thresholds for emigration is an issue on which past research offers mixed answers. We can be certain only about conclusions at a high level of generality: the phrase "poverty breeds emigration" is a clear example of this. On the other hand, conclusions relating to one emigration area are frequently counterbalanced by their opposites in another. For instance, Icduygu's (1991) study of Turkish migrants to Australia showed that pioneer migrants from several Anatolian villages were persons from the poorer households, while the AbadanUnat et al. (1976: 175) study of Turkish emigrants from Bogazliyan district found that they were mainly from households at the middle of economic ladder.

In general, the theoretical arguments and research findings for linking socioeconomic development and emigration are usually persuasive, but not comprehensive enough to pinpoint the essentials of this linkage. By analysing empirical data from Turkey, this study provides additional evidence that a threshold of socio-economic development may lead to a higher level of emigration: emigration is expected to increase when socio-economic development becomes poor, but then seems to decline when poverty becomes more extreme. Neither the richest areas nor the poorest ones contain the main participants in emigration. Data used in this study were, of course, insufficient to determine the extent to which differences in level of socio-economic development caused differences in emigration flows. The only way to rule out the possibility that other (social, political, cultural, and demographic) factors caused the variation is to use a multivariate model for comparison. ${ }^{17}$ Some obvious deviations in the findings of this study, which are already elaborated and explained above, increase our questioning in this context. Overall, these results highlight the importance of distinguishing between socio-economic causes and other non-economic causes in attempting to assess the relationship between socio-economic development and emigration.

Although much has changed in Turkey since the early 1960s in both the volume and type of emigration, the heavy involvement of middle-level developed districts in emigration continues to be significant. Poorest districts remain inhibited from improving their socio-economic development by their persistent distance from emigration. Clearly, this situation is incompatible with the claim 
of positive effects of the emigration process for the development of backward areas in the sending societies and on the improvement of regional disparities. Considering the long-standing issues relating to the effects of emigration on the development of the sending countries, for instance dilemmas of "balanced growth and asymmetric growth models", ${ }^{18}$ further research should be undertaken on how socio-economic development in a region operates as both causes and consequences of emigration.

\section{NOTES}

1. Cited by Kearney (1986: 331).

2. For a more detailed discussion on these issues, see Portes (1978); Portes and Borocz (1989); Piore (1980); Standing (1981); Portes and Bach (1985); Kearney (1986); Massey et.al. (1993); Hammar et.al. (1997); and Faist (2000).

3. See, for instance, van der Erf and Heering (1995).

4. See, for instance, Adepoju and Appleyard (1996).

5. See, for instance, Bocker (1995) and Fergany (1989).

6. See two recent studies: Hammar et al. (1997); and Faist (2000).

7. See, for instance, Bauer and Zimmerman (1995) for an outline of the theories focusing on economic and econometric issues for modelling international migration.

8. For an overview of the development-migration relationship as examined with the perspective of "causes and/or consequences", see Portes and Bach (1985), Massey et al. (1993, 1994). Massey (1988), using an historical perspective, describes mechanisms in which economic development leads to further migration.

9. For a detailed discussion on dual labour market approach, see chapters 2 and 4 of Piore (1980), and see also theoretical evaluations of Massey et al. (1993: 440-444 and 454-463).

10. The study Simmons (1989: 159-172) offers a compact description of world system theory in relation to international migration.

11. Other authors found similar results in the cases of internal migration: Greenwood (1971: 259-261), Skeldon (1977: 401), and Gedik (1996: 4-5).

12. For a detailed elaboration of this question, refer to recent studies by Hammar et al. (1997), Faist (2000).

13. As discussed by Piore (1980: 136), the nature of the areas involved in emigration can be understood in terms of the physical and institutional structure of the emigration process itself.

14. For a fuller description of the DSDI, see Dincer (1996).

15. See SIS (1993: 194).

16. In the Eastern and South-eastern regions of Turkey there have been ongoing clashes between the Turkish army and Kurdish (nationalist) guerrilla groups since the early 1980s. Consequently, millions of the persons from these regions have fled to both the western parts of the country and abroad.

17. Unfortunately, measures for these factors at the district level are quite difficult to obtain. Even in the absence of controls for these factors, we have provided solid confirmation of the curvilinear hypothesis.

18. See Keles (1985: 54-55). 


\section{REFERENCES}

Abadan-Unat, N.

1976 “Turkish migration to Europe, 1960-1977”, in N., Abadan-Unat (Ed.), Turkish Workers in Europe, 1960-1975, E.J. Brill, Leiden.

Abadan-Unat, N. et al.

1976 Migration and Development, Ajans-Türk Press, Ankara.

Adepoju, A., and R. Appleyard

1996 "The relevance of research on emigration dynamics for policy makers in SubSaharan Africa", International Migration, 34(2): 321-333.

Appleyard, R.

1995 "New trends in migration: numbers, directions and dynamics", paper presented at the Euroconference on Migration and Multiculturalism, 30 August-2 September 1995, London.

Bahadir, S.A.

1979 "Turkey and the Turks in Germany", Aussenpolitic, first quarter: 104-115.

Bauer, T., and K. Zimmermann

1995 "Modelling international migration: economic and econometric issues", in R. van der Erf and L. Heering (Eds), Causes of International Migration, Office for Official Publications of the European Communities, Luxembourg: 95-116.

Bocker, A.

1995 "Migration networks: Turkish migration to Western Europe", in R. van der Erf and L. Heering (Eds), Causes of International Migration, Office for Official Publications of the European Communities, Luxembourg.

Dincer, B.

1996 Ilcelerin Sosyo-Ekonomik Gelismislik Siralamasi [Socio-Economical Development Index of Subprovinces], DPT Bölgesel Gelisme ve Yapisal Uyum Genel Müdürlügü, Ankara.

Faist, T.

2000 The Volume and Dynamics of International Migration and Transnational Social Spaces, Clarendon Press, Oxford.

Fergany, N.

1989 "The international migration process as a dynamic system", in International Population Conference, IUSSP, New Delhi: 145-158.

Franz, E.

1994 Population Policy in Turkey, Deutsches Orient-Institut, Hamburg.

Gedik, A.

1996 "Internal migration in Turkey, 1965-1985: test of some conflicting findings in the literature", ANU Working Papers in Demography, Canberra.

Gokdere, A.

1994 "An evaluation of Turkey's recent migration flows and stocks", The Turkish Journal of Population Studies, 16: 29-56.

Greenwood, M.J.

1971 "A regression analysis of migration to urban areas of a less-developed country: the case of India", Journal of Regional Science, 11(2): 253-262. 
Hammar, T.

1995 "Development and immobility: why have not many more emigrants left the South?", in R. van der Erf and L. Heering (Eds), Causes of International Migration, Office for Official Publications of the European Communities, Luxembourg: 173-186.

Hammar, T., G. Brochmann, K. Tamas, and T. Fiast

1997 International Migration, Immobility and Development, Berg, Oxford. Icduygu, A.

1991 Migrant as a Transitional Category: Turkish Migrants in Melbourne, Australia, unpublished Ph.D. Thesis, Australian National University, Canberra.

1995 "Population, poverty, and culture: identifying the economic and social mechanisms for migration in Turkey", paper presented at the Euroconference on Policy in and Environment of Insecurity, 8-11 November, Lisbon.

1996 "Migration from Turkey to Western Europe: recent trends and prospects", paper submitted to Mediterranean Conference on Population, Migration and Development, 15-17 October, Palma de Mallorca.

Kearney, M.

1986 "From the invisible hand to visible feet", Annual Review of Anthropology, (15): 331-361.

Keles, R.

1995 "The effects of external migration on regional development in Turkey", in R. Hudson and J. Lewis (Eds), Uneven Development in Southern Europe, Methews and Co., New York.

Lieberman, S.S., and A.S. Gitmez

1979 "Turkey", in R.E. Krane (Ed.), International Labour Migration in Europe, Praeger Publishers, New York.

Massey, D.S.

1988 "Economic development and international migration in comparative perspective", Population and Development Review, 14(3): 383-413.

Massey, D.S., J. Arango, G. Hugo, A. Kouaouci, A. Pellegrioni, and J.E. Taylor

1993 "Theories of international migration: review and appraisal", Population and Development Review, 19(3): 431-466.

1994 "International migration theory: the North American Case", Population and Development Review, 20(4): 699-751.

Paine, $\mathrm{S}$.

1974 Exporting Workers: the Turkish Case, Cambridge University Press, Cambridge.

Piore, M.J.

1980 Birds of Passage. Migrant Labor and Industrial Societies, Cambridge University Press, Cambridge, UK.

Portes, A.

1978 "Migration and underdevelopment", Politics and Society, 8(1): 1-48.

Portes. A., and J. Borocz

1989 "Contemporary immigration: theoretical perspectives on its determinants and modes of incorporation", International Migration Review, 23(3): 606-630. 
Portes, A., and R.L. Bach

1985 Latin Journey, University of California Press, London.

Simmons, A.B.

1989 "World system-linkages and international migration: new directions in theory and method, with an application to Canada", in International Population Conference, IUSSP, New Delhi: 159-172.

SIS (State Institute of Statistics) 19931990 Census of Population, SIS Printing Division, Ankara.

Skeldon, R.

1977 "The evaluation of migration patterns during urbanization in Peru", Geographical Review, 67: 394-411.

Standing, G.

1981 "Migration and modes of exploitation", The Journal of Peasant Studies, 8(2): 173-210.

Van der Erf, R., and L. Heering (Eds)

1995 Causes of International Migration, Office for Official Publications of the European Communities, Luxembourg.

Young, C.M.

1983 "Education, employment, and the Turkish community in Australia", International Journal of Turkish Studies, 2(2): 33-57. 
FIGURE 1

TURKISH LABOUR EMIGRATION, 1961-1995

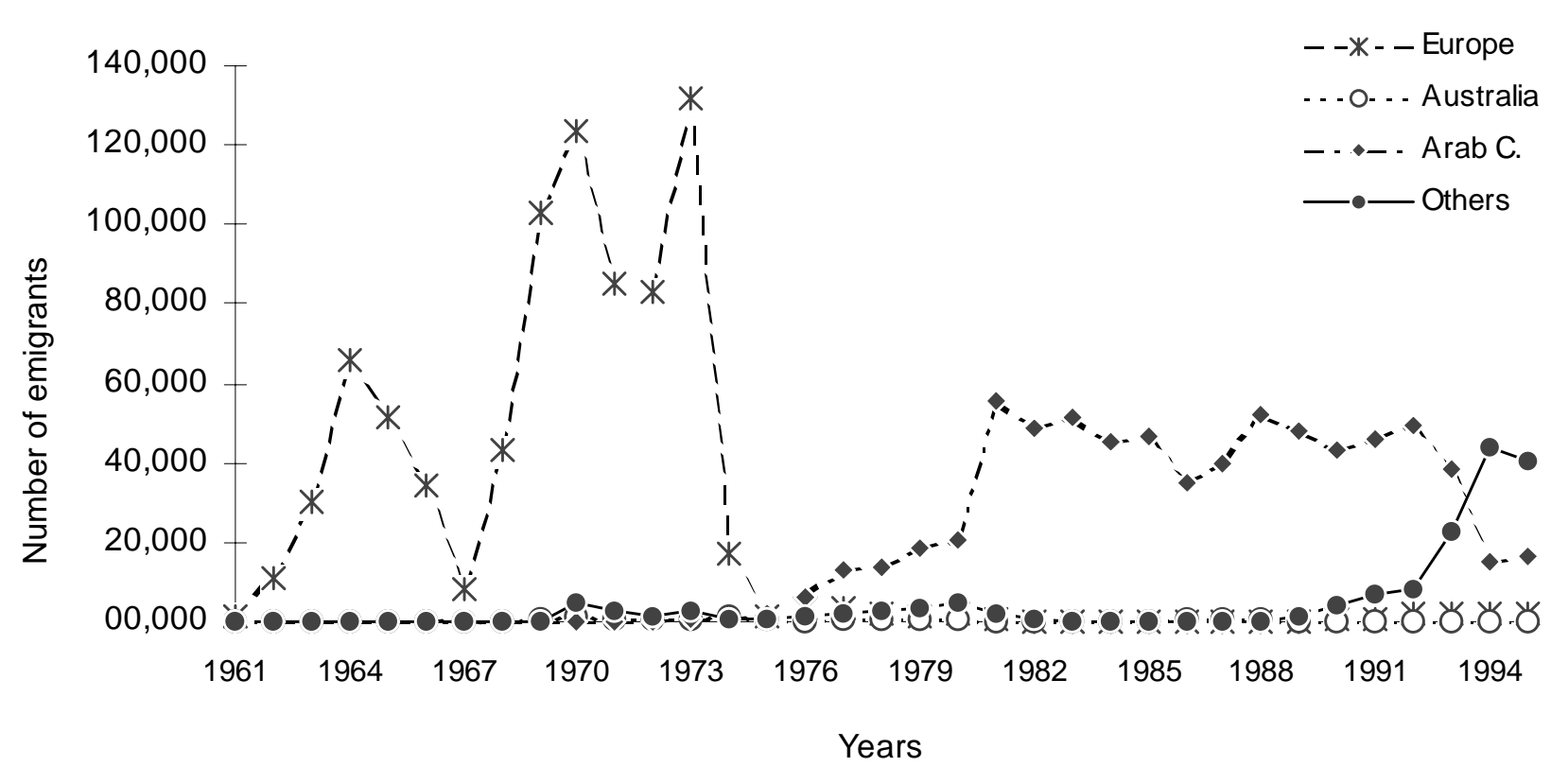

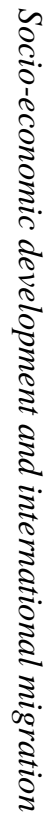


FIGURE 2

MEAN EMIGRATION AND SPO DEVELOPMENT LEVELS

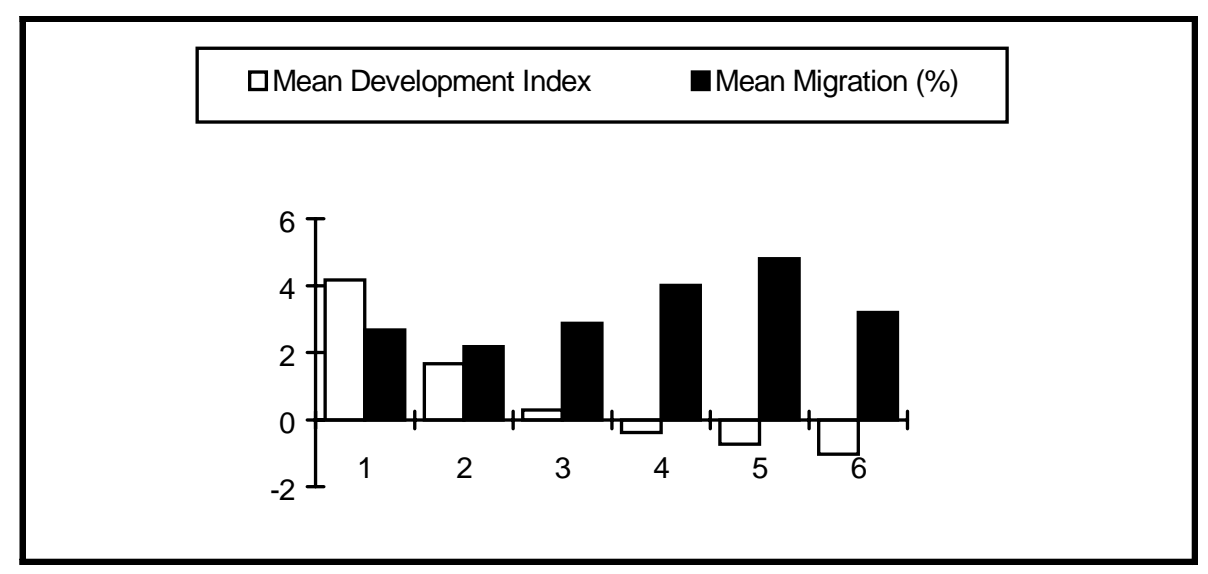

Note: In each twin-bar group the first bar represents the mean development index according to the SPO classification from 1 through 6 and the second bar represents the mean migration at that development level.

FIGURE 3

MEAN EMIGRATION AND DEVELOPMENT DECILES

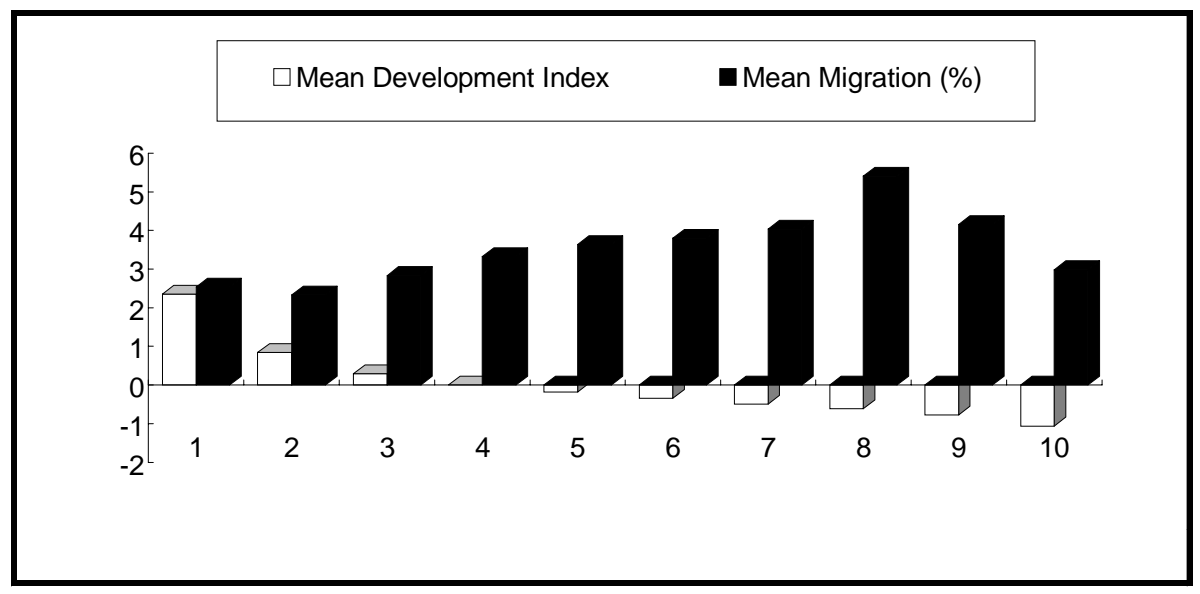

Note: In each twin-bar group, the first bar represents the mean development index of each development decile from 1 through 10 and the second bar represents the mean emigration proportion at that development decile. 
FIGURE 4

MIGRATION BY GEOGRAPHICAL REGIONS

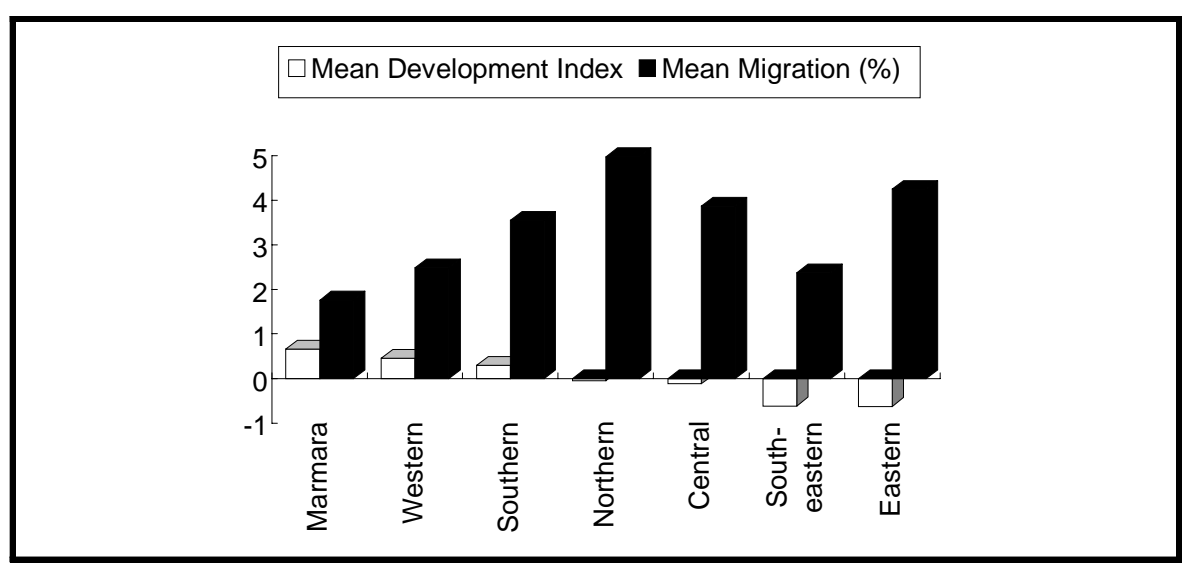

Note: In each twin-bar group, the first bar represents the mean development index of each geographical region ranked from the most developed (Marmara) to the least developed (Eastern) and the second bar represents the mean emigration proportion at that geographical region.

TABLE 1

DESCRIPTIVE STATISTICS

\begin{tabular}{|l|cc|}
\hline & Emigration & Development index \\
\hline Mean & 3.51 & 0.001 \\
Standard Deviation & 3.82 & 1.00 \\
Median & 2.1 & -0.25 \\
Mode & 1.2 & -0.60 \\
Minimum & 0.2 & -1.35 \\
Maximum & 31.1 & 7.77 \\
Skewness & 2.75 & 2.27 \\
Kurtosis & 9.99 & 8.46 \\
\hline
\end{tabular}

Source: (1) Emigration figures are from the 1990 Census, Question 5. They represent the percentage of households that have emigrants at the household level.

(2) Development index figures are the index values of the 1995 DSDI at the district level. 
TABLE 2

MEAN EMIGRATION AT SPO DEVELOPMENT LEVELS*

\begin{tabular}{|c|c|c|c|c|c|c|c|}
\hline $\begin{array}{l}\text { SPO } \\
\text { Development } \\
\text { Level }\end{array}$ & $\begin{array}{c}\text { Mean } \\
\text { Development } \\
\text { Index (DSDI) }\end{array}$ & $\begin{array}{c}\text { Mean } \\
\text { Emigration } \\
\text { (per cent) }\end{array}$ & $\begin{array}{c}\text { Development } \\
\text { Level } \\
2\end{array}$ & $\begin{array}{c}\text { Development } \\
\text { Level } \\
3\end{array}$ & $\begin{array}{c}\text { Development } \\
\text { Level } \\
4\end{array}$ & $\begin{array}{c}\text { Development } \\
\text { Level } \\
5\end{array}$ & $\begin{array}{c}\text { Development } \\
\text { Level } \\
6\end{array}$ \\
\hline 1 & 4.1641 & 2.6867 & $\begin{array}{l}t=1.12 \\
p=0.14\end{array}$ & $\begin{aligned} t & =0.60 \\
p & =0.27\end{aligned}$ & $\begin{aligned} t & =4.12 \\
p & =0.00\end{aligned}$ & $\begin{array}{l}t=3.66 \\
p=0.00\end{array}$ & $\begin{array}{l}t=1.21 \\
p=0.11\end{array}$ \\
\hline 2 & 1.6758 & 2.1836 & - & $\begin{array}{r}t=1.88 \\
p=0.03\end{array}$ & $\begin{aligned} t & =5.60 \\
p & =0.00\end{aligned}$ & $\begin{array}{l}t=4.33 \\
p=0.00\end{array}$ & $\begin{array}{l}t=2.07 \\
p=0.02\end{array}$ \\
\hline 3 & 0.2929 & 2.8736 & - & - & $\begin{array}{r}t=3.82 \\
p=0.00\end{array}$ & $\begin{array}{l}t=3.41 \\
p=0.00\end{array}$ & $\begin{array}{l}t=0.82 \\
p=0.20\end{array}$ \\
\hline 4 & -0.3721 & 4.0077 & - & - & - & $\begin{array}{l}t=1.30 \\
p=0.10\end{array}$ & $\begin{array}{l}t=1.94 \\
p=0.03\end{array}$ \\
\hline 5 & -0.7322 & 4.8041 & - & - & - & - & $\begin{array}{l}t=2.48 \\
p=0.01\end{array}$ \\
\hline 6 & -1.0296 & 3.1990 & - & - & - & - & - \\
\hline
\end{tabular}

*Source: Tests for differences in mean emigration at different development levels are reported in columns 4 through 8 . In these columns, the first number presents the absolute value of the t-statistic, and the second the p-value that shows the twotailed significance level of the difference between the two means. 
TABLE 3

MEAN EMIGRATION AT DEVELOPMENT DECILES

\begin{tabular}{|l|ccr|}
\hline Development Level & $\begin{array}{c}\text { Mean Development } \\
\text { Index }\end{array}$ & $\begin{array}{c}\text { Mean Emigration } \\
\text { (per cent) }\end{array}$ & t-test results $^{*}$ \\
\hline 1st Decile & 2.3500 & 2.53 & $2,3,10$ \\
2nd Decile & 0.8412 & 2.33 & 1,3 \\
3rd Decile & 0.2903 & 2.83 & $1,2,4,10$ \\
4th Decile & 0.0003 & 3.32 & $3,5,6,7,9,10$ \\
5th Decile & -0.1770 & 3.63 & $4,6,7,9,10$ \\
6th Decile & -0.3418 & 3.79 & $4,5,10$ \\
7th Decile & -0.4926 & 4.03 & $4,5,8,9$ \\
8th Decile & -0.6118 & 5.41 & 7,9 \\
9th Decile & -0.7745 & 4.15 & $4,5,7,8$ \\
10th Decile & -1.0597 & 2.98 & $1,3,4,5,6$ \\
\hline
\end{tabular}

Note: Differences in mean emigration proportions at different development deciles are tested by conducting t-tests. Numbers reported in column 4 relate to development decile numbers whose mean emigration proportion is not different from the one represented in that particular row at the 10 per cent significance level; i.e., the $p$-value of the t-statistics that shows the two-tailed significance level of the difference between the two means is greater than 10 per cent.

TABLE 4

MIGRATION BY GEOGRAPHICAL REGIONS

\begin{tabular}{|l|ccr|}
\hline $\begin{array}{l}\text { Geographical } \\
\text { Region }\end{array}$ & $\begin{array}{c}\text { Mean Development } \\
\text { Index }\end{array}$ & $\begin{array}{c}\text { Mean Migration } \\
\text { (per cent) }\end{array}$ & t-test results $^{*}$ \\
\hline Marmara (M) & 0.66 & 1.76 & - \\
Western (W) & 0.46 & 2.48 & SE \\
Southern (S) & 0.30 & 3.55 & N, E \\
Northern (N) & -0.04 & 4.98 & S, E \\
Central (C) & -0.12 & 3.87 & E \\
South-eastern (SE) & -0.61 & 2.37 & W \\
Eastern (E) & -0.62 & 4.25 & S, N, C \\
\hline
\end{tabular}

Note: Differences in mean emigration proportions at different geographical regions are tested by conducting t-tests. Letters reported in column 4 relate to the geographical region symbols whose mean emigration proportion is not different from the one represented in that particular row at the 10 per cent significance level; i.e., the $p$-value of the t-statistics that shows the two-tailed significance level of the difference between the two means is greater than 10 per cent. 


\title{
DEVELOPPEMENT SOCIO-ECONOMIQUE ET MIGRATION INTERNATIONALE: UNE ETUDE TURQUE
}

\author{
"Les causes et les conséquences de la migration interne continue et de la \\ migration internationale sont au cour du problème contemporain de \\ développement." M.P. Todaro
}

Les causes profondes de la migration internationale ont fait l'objet de nombreuses études, dont une grande majorité s'appuient sur des théories du développement guidées par des impératifs économiques. Une hypothèse sousjacente est l'idée selon laquelle la pauvreté alimente les flux migratoires. Les résultats de ces études, et les conclusions qui en sont tirées, divergent largement. Par exemple, les recherches n'ont pas permis de donner une réponse tranchée à la question de savoir si l'émigration augmente à mesure que la pauvreté s'aggrave, ou au contraire lorsqu'elle régresse, ni à celle de savoir pour quelle raison elle atteint un niveau donné.

Le présent article examine le rapport entre le développement économique et la migration en prenant en considération les degrés de développement économique qui constituent des seuils pour la migration. Il met l'accent sur les témoignages récents qu'offre le rapport entre le développement et l'émigration en Turquie, lequel rapport reflète la dynamique et les mécanismes qui favorisent ou limitent les flux migratoires au départ de ce pays.

Le but principal de cet article, qui s'appuie sur les données fournies par l'Index de développement socio-économique de la Turquie au niveau des districts pour 1995 et sur le recensement de 1990, est de donner une base analytique indiquant les paliers du niveau de développement local en Turquie, de rapporter ceux-ci aux flux migratoires internationaux, et d'examiner les formes que prend ainsi le rapport développement/migration.

\section{DESARROLLO SOCIOECONÓMICO Y MIGRACIÓN INTERNACIONAL: UN ESTUDIO TURCO}

\author{
"Las causas y consecuencias de la migración interna e internacional \\ continua residen en la esencia misma del problema de desarrollo \\ contemporáneo.” M.P. Todaro
}

Las causas originarias de la migración internacional han sido objeto de muchos estudios, gran mayoría de los cuales se basó en teorías de desarrollo dominadas 
por perspectivas orientadas hacia la economía. Una suposición subyacente es que la pobreza engendra migración. Los resultados y conclusiones de estos estudios difieren enormemente. Por ejemplo, no se ha podido determinar a través de la investigación si la emigración aumenta cuando se agudiza la pobreza o cuando es menos aguda, o por qué alcanza ciertos niveles.

Este artículo investiga la relación entre el desarrollo económico y la migración teniendo en cuenta los grados de desarrollo económico que conforman los umbrales de la migración. Se concentra en pruebas recientes sobre la relación entre desarrollo y emigración en Turquía, lo que refleja una dimensión de la dinámica y de los mecanismos que fomentan o restringen las corrientes migratorias desde ese país.

Utilizando datos del Índice Socioeconómico de Desarrollo Distrital (DSDI) de 1995 en Turquía y del Censo de 1990, el objetivo principal de este artículo es ofrecer una base analítica que identifique los grados de desarrollo local en Turquía, relacionarlos con las corrientes migratorias internacionales, y examinar los patrones de la relación entre desarrollo y migración. 